\title{
ІНВЕСТИЦІЙНЕ ЗАБЕЗПЕЧЕННЯ РОЗВИТКУ ПІДПРИЄМСТВ ТИМЧАСОВОГО РОЗМІЩЕННЯ УКРАЇНИ
}

\section{INVESTMENT SUPPORT FOR THE DEVELOPMENT OF TEMPORARY ACCOMMODATION ENTERPRISES OF UKRAINE}

\author{
Мархонос Світлана Миколаївна \\ кандидат географрічних наук, доцент, \\ Національний авіаційний університет \\ ORCID: https://orcid.org/0000-0002-6615-5262 \\ Турло Наталія Платонівна \\ кандидат економічних наук, доцент, \\ Академія праці, соціальних відносин і туризму \\ ORCID: https://orcid.org/0000-0002-0007-7521 \\ Markhonos Svitlana \\ National Aviation University, \\ Turlo Natalija \\ Academy of Labour, Social Relations and Tourism
}

\begin{abstract}
Стаття присвячена актуальним питанням визначення рівня інвестиційного забезпечення розвитку підприємств тимчасового розміщення в Україні. Проаналізовано динаміку та джерела капітальних інвестицій в економіку України та у засоби тимчасового розміщення. Досліджено, що формування інвестиційних ресурсів підприємств тимчасового розміщення відбувається здебільшого за рахунок власних коштів підприємств та організацій. Визначено тенденції розвитку інвестиційних процесів у засоби тимчасового розміщення та здійснено прогнозування їх обсягів. Виокремлено перспективні напрями інвестування підприємств тимчасового розміщення України та визначено основні заходи для створення привабливого інвестиційного клімату у сфері гостинності.

Ключові слова: інвестиції, інвестиційне забезпечення, сфрера гостинності, підприємства тимчасового розміщення, інвестиційні джерела.
\end{abstract}

Статья посвящена актуальным вопросам определения уровня инвестиционного обеспечения развития предприятий временного размещения в Украине. Проанализированы динамика и источники капитальных инвестиций в экономику Украины и в средства временного размещения. Исследовано, что формирование инвестиционных ресурсов предприятий временного размещения происходит в основном за счет собственных средств предприятий и организаций. Определены тенденции развития инвестиционных процессов в средства временного размещения и спрогнозировано их объемы. Выделены перспективные направления инвестирования предприятий временного размещения Украины и определены основные мероприятия по созданию привлекательного инвестиционного климата в сорере гостеприимства.

Ключевые слова: инвестиции, инвестиционное обеспечение, сфера гостеприимства, предприятия временного размещения, инвестиционные источники.

The article is devoted to topical issues of determining the level of investment support of the development of temporary accommodation enterprises in Ukraine. The dynamics and sources of capital investments in the economy of Ukraine and in the means of temporary accommodation are analyzed. It is determined that the investment attractiveness of the hotel industry is influenced by both external (investment attractiveness of the country, industry and region) and internal factors (specialization, state of material and technical base, staffing and marketing, goodwill, financial and property status). It was researched that the formation of investment resources of temporary accommodation enterprises is mainly happening at the expense of own funds of enterprises and organizations. The processed statistics shows the instability of the dynamics of capital investment in the hospitality industry and the rapid change of periods of growth and decline in investment in this activity. Trends in the development of investment processes in the means of temporary accommodation are identified and their volumes are forecasted. It is noted that an important 
source of financing the investment activities of temporary accommodation enterprises in Ukraine is foreign direct investment, which is formed at the expense of share capital and debt to direct investors on debt instruments. Promising areas of investment of temporary accommodation enterprises in Ukraine include investment in the construction of new and purchase of already built hotels, as well as the reconstruction of hotels; investing in the purchase of hotel rooms and apartments; investing in hotel management, modern technology, staff training, etc; purchase of a well-known brand (franchise). It is determined that in order to create an attractive investment climate in the field of hospitality it is necessary to: ensure the introduction of mechanisms of economic stimulation of investment activities of enterprises; attraction of long-term foreign loans in the development of hospitality; increasing the effectiveness of tax levers and intensifying budget funding for temporary accommodation; directing funds from local budgets to the development of tourist infrastructure and promotion of regional tourism product.

Keywords: investments, investment provision, hospitality sphere, temporary accommodation enterprises, investment sources.

Постановка проблеми. Підприємства тимчасового розміщення - важлива складова успішного розвитку туристичної сорери. Аналіз рівня інвестиційного забезпечення розвитку підприємств тимчасового розміщення в Україні дасть можливість визначити основні джерела інвестування та шляхи їх розширення, також дасть можливість сформувати комплекс заходів спрямованих на удосконалення інвестиційної привабливості сорери гостинності та допоможе сорормувати перспективні напрями розвитку підприємств тимчасового розміщення та їх інвестиційного забезпечення.

Аналіз останніх досліджень та публікацій. Багатоаспектні питання впливу фрінансових важелів на реалізацію інвестиційного процесу ґрунтовно висвітлили у своїх працях такі вітчизняні науковці, як І.О. Бланк, Т.В. Майорова, І.П. Параска, І.О. Петровська та ін. Теоретичним і практичним аспектам фрінансового забезпечення інвестиційної діяльності підприємств сфрери гостинності присвячено велику кількість наукових праць вітчизняних та зарубіжних фрахівців. Серед них слід назвати таких науковців, як Л.О. Алещенко, Н.І. Данько, І.М. Ощипок, І.О. Соколовська, Г.М. Тарасюк, А.О. Чагайда, Г.О. Фесенко.

Формулювання цілей статті. Метою статті $€$ діагностика сучасного стану інвестиційного забезпечення підприємств тимчасового розміщення України, виявлення фракторів, що гальмують розвиток бізнес-клімату в країні та визначення основних напрямів подальшого інвестування підприємств сорери гостинності.

Виклад основного матеріалу. Незважаючи на декларування кардинального рефрормування економіки України, інвестиційний клімат в країні залишається несприятливим. Так, інтегральний показник Індексу інвестиційної привабливості України, обчислений в результаті експертного дослідження, проведеного Європейською Бізнес Асоціацією (ЄБА), у другому півріччі 2021 року становив
2,73 бали з 5 можливих за шкалою Лайкерта, що на 0,11 балів нижче ніж у першому півріччі 2021 р. (найвищим протягом 2014-2021 рр. він був в першому півріччі 2017 р. і склав 3,17 бали 35 можливих) [1].

До основних фракторів, що стримують розвиток бізнес-клімату належать: слабка судова система, високий рівень корупції, тіньова економіка. В 2021 р. вперше до цього списку додався низький темп вакцинації населення. До інших перепон зростання інвестиційної привабливості України слід віднести геополітичну напруженість, енергетичну кризу, недосконале державне управління, стагнацію ресрорм, складну податкову систему, постійні ротації в Уряді та інше [1].

Серед фракторів, які позитивно впливають на бізнес-клімат в останній час, виділяють співпрацю з МВФ, стабільний валютний курс, діджиталізацію державних послуг, валютне регулювання, запуск ринку землі та реформу містобудування.

Напрям зміни обсягу капітальних інвестицій в країні щороку виявляє певну варіативність під впливом макроекономічних чинників. Політична нестабільність, що мала місце в Україні наприкінці 2013 р. переросла у масштабну кризу та зумовила зниження обсягу капітальних інвестицій у 2013 р. на 8,84\% порівняно 3 2012 р. Падіння продовжилось надалі у 2014 р. та становило 12,2\%. За 2020 рік в економіку України було залучено 419,84 млрд грн капітальних інвестицій, що на 32,7\% менше, ніж за 2019 рік, а за дев'ять місяців 2021 р. загальний обсяг капітальних інвестицій становив 331,7 млрд. грн. (таблиця 1).

Як видно 3 даних, наведених в таблиці 1, протягом 2013-2020 рр. у структурі капітальних інвестицій за усіма видами економічної діяльності значна частка належала власним коштам підприємств та організацій $(70,8 \%$ у 2018 р., що $€$ максимальним значенням за аналізований період). Другу позицію займають кредити банків та інші позики (у серед- 


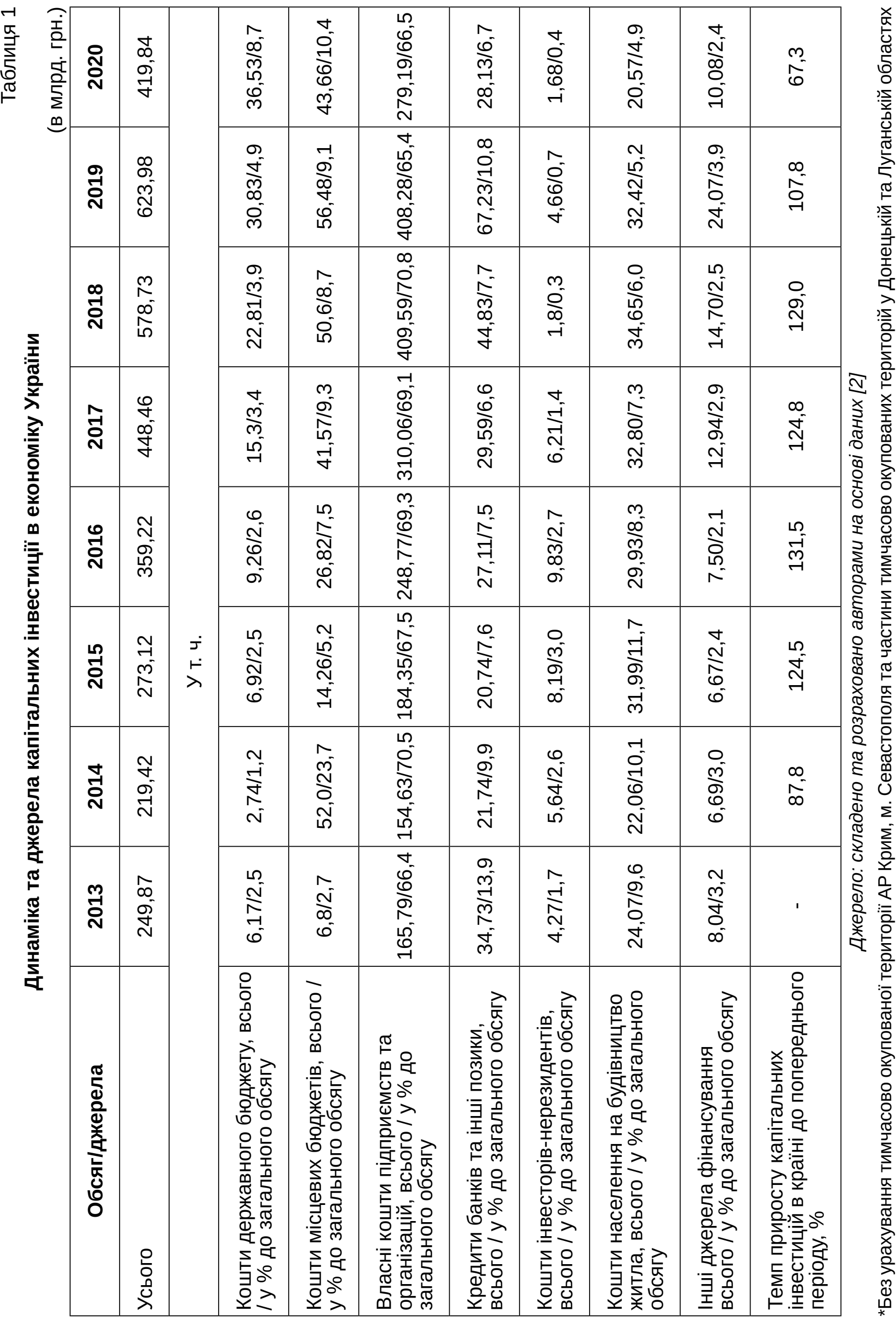


ньому за десять років становить 13,7\%), третю - кошти населення на будівництво житла (у середньому за десять років - 8,5\%). Така структура пов'язана із недостатнім рівнем розвитку фрінансового ринку, низькою інвестиційною привабливістю підприємств, високою вартістю залучення зовнішніх фрінансових ресурсів, обмеженими можливостями державного та місцевих бюджетів. Отже, вітчизняні компанії вимушені переважно розраховувати на внутрішні запаси інвестиційних ресурсів.

Що стосується підприємств готельного господарства, то на їх інвестиційну привабливість впливають як зовнішні (інвестиційна привабливість країни, галузі та регіону), так і внутрішні фрактори (спеціалізація, стан матеріально-технічної бази, кадрове та маркетингове забезпечення, гудвіл, фрінансово-майновий стан).

Протягом 2011-2012 рр. темп приросту капітальних інвестицій у сореру гостинності значно перевищував зазначений показник у цілому по країні. Так, темп приросту капітальних вкладень у цей період у підприємства 3 тимчасового розміщення становив 52,22\%. Водночас протягом 2013-2014 рр. характерним стало значне падіння рівня фрінансування інвестиційної діяльності у сорері туризму, що можна пояснити загальним зниженням ділової активності в країні, зменшенням туристичних потоків у зв'язку з проведення антитерористичної операції на сході України, тощо. Упродовж 2015-2018 рр. інвестиції в заклади розміщення збільшилися в 1,7 рази (від 890,2 млн. грн. у 2015 р. до 1473,0 млн. грн. у 2018 р.) [2].

Протягом 2018-2020 рр. питома вага капітальних інвестицій освоєних готельними підприємствами в Україні становила в середньому 0,19\% до загального обсягу по країні (за інфрормацією Всесвітньої ради з туризму та подорожей, на сореру гостинності припадає 4,3\% загального обсягу інвестицій) (таблиця 2). Зрозуміло, що даний рівень $є$ недостатнім, а обсяги залучення інвестицій у сореру гостинності $€$ незначними порівняно з іншими пріоритетними галузями економіки.

За опублікованими даними Державної служби статистики України, у 2020 р. капітальні інвестиції в заклади тимчасового розміщення становили 609,824 млн. грн., що на 38,0\% менше, ніж у попередньому періоді, коли ця величина дорівнювала 982,9 млн. грн. та на 58.6\% менше у порівнянні 32018 р. (від 1473,0 млн. грн. у 2018 р. до 609,824 млн. грн. у 2020 р.).
Отже, наведені дані свідчать про нестабільність динаміки капітальних інвестицій у сореру гостинності та швидку зміну періодів зростання та зменшення обсягу інвестицій у цей вид діяльності.

Впродовж 2018-2020рр. із загального обсягу капітальних інвестицій, спрямованих у засоби тимчасового розміщення, кошти більшою мірою були акумульовані та освоєні в м. Києві, Дніпропетровській, Львівській, Одеській, Харківській областях.

Формування інвестиційних ресурсів підприємств тимчасового розміщення відбувається здебільшого за рахунок власних коштів підприємств та організацій. Частка цих коштів у загальному обсягу інвестицій у заклади розміщення становила у 2018 р. 86,9\%, 2019 р. 90,5\%, 2020 р. - 93,1\%. Розширення інвестиційної діяльності за рахунок власних коштів можливе при умові зниження податкового навантаження; надання можливості суб'єктам господарювання використовувати як рівномірну, так і прискорену амортизацію відповідно до цілей діяльності; створення на підприємствах відповідно облікової політики фонду відновлення 3 метою цільового використання амортизаційних відрахувань на інвестиційні потреби.

Витрати державного та місцевих бюджетів на розвиток підприємств тимчасового розміщення незначні. В 2018 р. вони становили 2,4\% від загальної суми інвестицій у засоби тимчасового розміщення, а в 2019 р. - 0,8\%. Інформація щодо обсягів інвестицій з державного бюджету в 2020 р. у сореру гостинності взагалі була конфріденційною, що не дає можливості оцінити витрати держави на її розвиток.

Ще одним джерелом фрінансування інвестиційної діяльності підприємств тимчасового розміщення в Україні є прямі іноземні інвестиції, що формуються за рахунок акціонерного капіталу й заборгованості перед прямими інвесторами за борговими інструментами.

За даними Державної служби статистики України темп приросту прямих іноземних інвестицій, залучених підприємствами гостинності, мав позитивну тенденцію тільки у 2011 р. (5,6\%), а в подальшому спостерігалось падіння на рівні 8,7-39,5\% річних. Що стосується періоду 2018-2020 рр. дане джерело не використовувалося зовсім. Зрозуміло, що за таких обставин не можна говорити про якісне виконання іноземними інвестиціями своєї ролі при фрінансуванні інвестиційної діяльності. Розвитку даного джерела залучення ресурсів в Україні пере- 
Таблиця 2

Динаміка та джерела інвестицій у засоби тимчасового розміщення України*

(млрд. грн.)

\begin{tabular}{|c|c|c|c|c|c|}
\hline & \multicolumn{3}{|c|}{ Роки } & \multicolumn{2}{|c|}{ Відхилення (士) 2020 р. від } \\
\hline & \multirow[b]{2}{*}{2018} & \multirow[b]{2}{*}{2019} & \multirow[b]{2}{*}{2020} & 2018 p. & 2019 p. \\
\hline & & & & $\begin{array}{l}\text { абс.I } \\
\text { відносне }\end{array}$ & $\begin{array}{c}\text { абс.I } \\
\text { відносне }\end{array}$ \\
\hline $\begin{array}{l}\text { Капітальні інвестиції за джерелами } \\
\text { фінансування за видами економічної } \\
\text { діяльності в Україні, усього }\end{array}$ & 578,73 & 623,98 & 419,84 & $-158,89 /-27,5$ & $-204,14 /-32,7$ \\
\hline Тимчасове розміщування, усього & 1,473 & 0,982 & 0,609 & $-0,864 /-58,7$ & $-0,373 /-38,0$ \\
\hline Частка в інвестиціях по Україні, \% & 0,25 & 0,16 & 0,15 & $-0,1$ & $-0,01$ \\
\hline Коштів державного бюджету, млн. грн. & 0,044 & 0,008 & $\mathrm{~K}$ & - & - \\
\hline $\begin{array}{l}\text { Частка в інвестиціях у засоби } \\
\text { тимчасового розміщення, \% }\end{array}$ & 2,987 & 0,815 & - & - & - \\
\hline Коштів місцевих бюджетів, млн. грн. & 0,035 & - & $\mathrm{K}^{\star \star}$ & - & - \\
\hline $\begin{array}{l}\text { Частка в інвестиціях у засоби } \\
\text { тимчасового розміщення, \% }\end{array}$ & 2,376 & - & - & - & - \\
\hline $\begin{array}{l}\text { Власних коштів підприємств та } \\
\text { організацій }\end{array}$ & 1,280 & 0,889 & 0,567 & & \\
\hline $\begin{array}{l}\text { Частка в інвестиціях у засоби } \\
\text { тимчасового розміщення, \% }\end{array}$ & 86,897 & 90,53 & 93,103 & $+6,206$ & $+2,573$ \\
\hline $\begin{array}{l}\text { Кредитів банків та інших позик } \\
3 \text { них - кредитів іноземних банків }\end{array}$ & $\begin{array}{c}0,106 \\
-\end{array}$ & $\begin{array}{c}0,044 \\
-\end{array}$ & $\begin{array}{l}\mathrm{K} \\
-\end{array}$ & - & - \\
\hline $\begin{array}{l}\text { Частка в інвестиціях у засоби } \\
\text { тимчасового розміщення, \% }\end{array}$ & 7,196 & 4,481 & - & - & - \\
\hline $\begin{array}{l}\text { Коштів вітчизняних інвестиційних } \\
\text { компаній, фрондів, тощо }\end{array}$ & - & - & $\mathrm{K}$ & - & - \\
\hline $\begin{array}{l}\text { Частка в інвестиціях у засоби } \\
\text { тимчасового розміщення, \% }\end{array}$ & - & - & - & - & - \\
\hline Коштів іноземних інвесторів & - & - & - & - & - \\
\hline $\begin{array}{l}\text { Частка в інвестиціях у засоби } \\
\text { тимчасового розміщення, \% }\end{array}$ & - & - & - & - & - \\
\hline
\end{tabular}

Джерело: складено та розраховано авторами на основі даних ДСС [2]

* без урахування тимчасово окупованої території АР Крим, м. Севастополя та частини тимчасово окупованих територій у Донецькій та Луганській областях

** дані $€$ коноріденційними

шкоджають наступні чинники: відсутність стабільної політичної й економічної ситуації; низький рівень конкурентоспроможності вітчизняних компаній (відсутність якісної інсрормації про туристичні регіони, нерозвиненість загальної інфрраструктури, особливо на рекреаційних територіях); втручання місцевих органів влади й органів контролю в туристичний бізнес; відмова підприємств від реалізації нових інвестиційних проектів на користь втілення стратегії утримання частки ринку та виживання.

В зв'язку 3 обмеженими можливостями використання іноземних інвестицій у більшості випадків відносини виникають 3 внутрішніми інвесторами, які готові вкласти від 2 до 10 млн. доларів. 70\% інвесторів прихо- дять зі своїм проектом і планом його розвитку. Лише $30 \%$ мають більш усвідомлений підхід до інвестування. Зазвичай вони ще не визначилися 3 конкретним проектом і розглядають варіанти вкладання грошей в портфель підприємства. Дохідність таких вкладень на внутрішньому ринку України становить 7-8\% (на зарубіжному - 3-4\%) [4].

Для характеристики інтенсивності інвестиційного процесу у засоби тимчасового розміщення України, на основі даних Державної служби статистики за 2010-2020 рр., авторами були розраховані середні показники його динаміки. Так, середній рівень інтервального ряду динаміки становить 1005,1 млн. грн., середній абсолютний приріст - 358,68 млн. грн., а середній темп зростання - 98,9\%. 


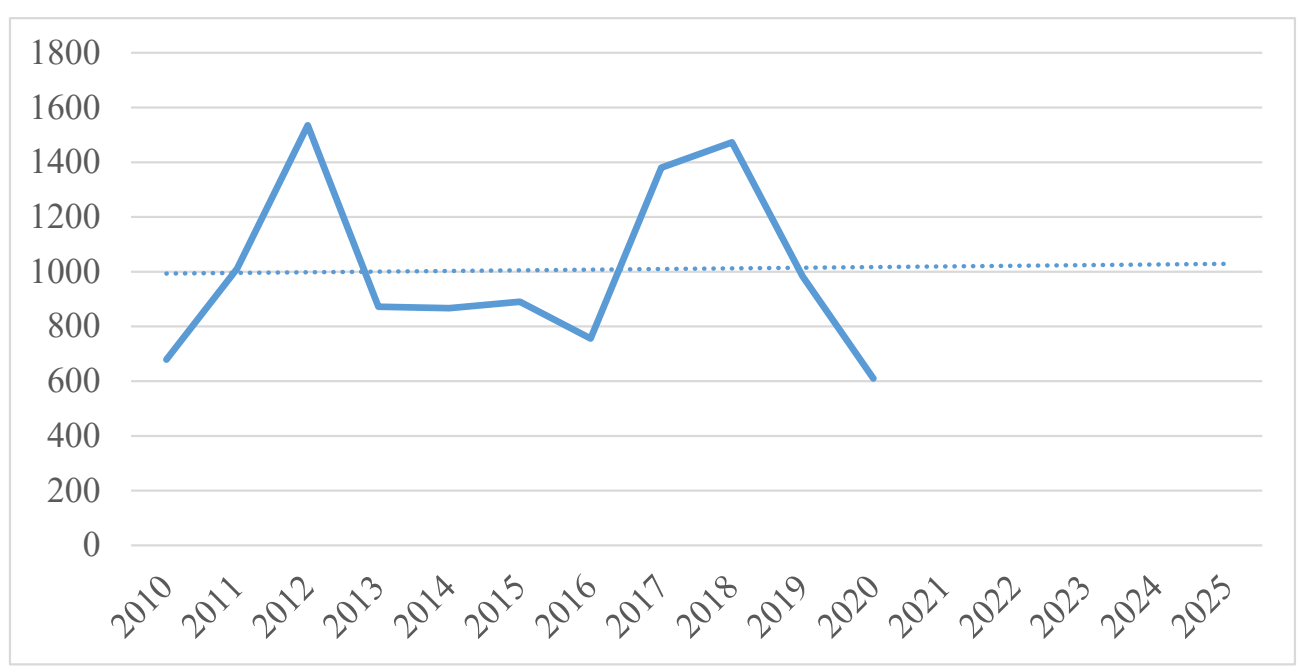

Рис. 1. Динаміка прогнозних значень обсягів інвестиційних вкладень В засоби тимчасового розміщення України

3 метою виявлення тенденції розвитку інвестиційних процесів у засоби тимчасового розміщення було застосовано кореляційнорегресійний аналіз, з використанням моделі парної лінійної регресії (рис. 1).

До перспективних напрямів інвестування підприємств тимчасового розміщення України можна віднести інвестування будівництва нових і купівлю вже побудованих готелів, а також реконструкцію готелів; вкладання коштів 3 метою купівлі готельних номерів й апартаментів; інвестування в управління готелями, в сучасні технології, підготовку персоналу тощо; купівля відомого бренда (фрраншиза) [5].

Крім цього, для активізації інвестиційної діяльності необхідно: відновити роль держави у підтримці інвестиційних процесів; створити умови для внутрішнього інвестування. 3 метою активізації інвестиційної діяльності, можливо використати наступні внутрішні джерела: амортизаційні відрахування; кошти від продажу цінних паперів; кошти населення; створення спеціального інвестиційного режиму підприємницької діяльності; стимулювати залучення прямих іноземних інвестицій.

Формою залучення іноземних інвесторів може бути передача їм: частки у статутному фонді, що відповідає розмірові інвестицій- ного вкладу; частки власності після реалізації проекту; відсотка від майбутнього прибутку; квоти місць (при будівництві об'єктів розміщення туристів); пільгове надання туристично-рекреаційних послуг.

Висновки. Для створення привабливого інвестиційного клімату у сорері гостинності необхідно: забезпечити впровадження механізмів економічного стимулювання інвестиційної діяльності підприємств; залучення довготермінових іноземних кредитів у розбудову сорери гостинності; підвищення дієвості податкових важелів та активізації бюджетного орінансування підприємств тимчасового розміщення; спрямування коштів місцевих бюджетів, на розбудову туристичної інорраструктури та популяризацію туристичного продукту. Отже, рівень інвестиційного забезпечення вітчизняних підприємств сорери тимчасового розміщення $€$ недостатнім. Зважаючи на світовий досвід реалізації інвестиційної діяльності у сорері гостинності, українські компанії мають значні нереалізовані можливості щодо ефрективного фрормування власних, залучених і запозичених інвестиційних ресурсів як на внутрішньому, так і на зовнішніх ринках 3 метою досягнення стійких темпів економічного зростання.

\section{СПИСОК ВИКОРИСТАНИХ ДЖЕРЕЛ:}

1. European Business Association (EBA). URL: https://eba.com.ua/wp-content/uploads/2021/12/EBAInvestIndex_2H-2021_UKR.pdf

2. Державна служба статистики України. URL: http://www.ukrstat.gov.ua

3. 30 років незалежності України: економічні підсумки. URL: https://uifuture.org/

4. Готельний бізнес в Україні: можливості та ризики. URL: https://ribashotelsgroup.ua/blog/gostinichniybiznes-v-ukraine-vozmozhnosti-i-riski/ 
5. Ощипок І.М. Перспектива інвестиційної діяльності у готельному бізнесі України. Вісник Львівського торговельно-економічного університету. Економічні науки. 2019. Вип. 57. С. 26-32. URL: http://lute.Iviv.ua/ fileadmin/www.lac.lviv.ua/data/DOI/2522-1205-2019-57-04.pdf

\section{REFERENCES:}

1. European Business Association (EBA). Available at: https://eba.com.ua/wp-content/uploads/2021/12/EBAInvestIndex_2H-2021_UKR.pdf

2. Derzhavna sluzhba statystyky Ukrainy (2012-2021). Kyiv: Informatsiino-analitychne ahentstvo.

3. 30 rokiv nezalezhnosti Ukrajinu: ekonomichni pidsumku. Available at: https://uifuture.org/

4. Ghoteljnyj biznes v Ukrajini: mozhlyvosti ta ryzyky. Available at: https://ribashotelsgroup.ua/blog/gostinichniy-biznes-v-ukraine-vozmozhnosti-i-riski/

5. Oshhypok I.M. (2019) Perspektyva investycijnoji dijaljnosti u ghoteljnomu biznesi Ukrajiny. Visnyk Ljvivsjkogho torghoveljno-ekonomichnogho universytetu. Ekonomichni nauky, vol. 57, pp. 26-32. Available at: http://lute.Iviv.ua/fileadmin/www.lac.lviv.ua/data/DOI/2522-1205-2019-57-04.pdf 